\title{
IACS: past, present, and future of the International Association of Cryospheric Sciences
}

\author{
Ian Allison ${ }^{1}$, Charles Fierz ${ }^{2}$, Regine Hock ${ }^{3}$, Andrew Mackintosh ${ }^{4}$, Georg Kaser ${ }^{5}$, and \\ Samuel U. Nussbaumer ${ }^{6}$ \\ ${ }^{1}$ Antarctic Climate and Ecosystems CRC, Hobart, Australia \\ ${ }^{2}$ WSL Institute for Snow and Avalanche Research SLF, Davos, Switzerland \\ ${ }^{3}$ Geophysical Institute, University of Alaska, Fairbanks, USA \\ ${ }^{4}$ Antarctic Research Centre, Victoria University of Wellington, Wellington, New Zealand \\ ${ }^{5}$ Institute for Atmospheric and Cryospheric Sciences, University of Innsbruck, Innsbruck, Austria \\ ${ }^{6}$ World Glacier Monitoring Service, Department of Geography, University of Zurich, Zurich, Switzerland \\ Correspondence: Ian Allison (ian.allison@utas.edu.au)
}

Received: 22 October 2018 - Revised: 4 December 2018 - Accepted: 4 December 2018 - Published: 16 April 2019

\begin{abstract}
The International Association of Cryospheric Sciences (IACS) became the eighth and most recent association of IUGG at the general assembly in Perugia, Italy, in July 2007. IACS was launched in recognition of the importance of the cryosphere within the Earth system, particularly at a time of significant global change. It was the first new association of the union to be formed in over 80 years and IACS celebrated its 10th anniversary only a year before the IUGG centennial. The forbearers of IACS, however, stretch back even further than IUGG, starting with the formation of the Commission Internationale des Glaciers (CIG) by the International Geological Congress in 1894. Here we record the history of the transition from CIG to IACS, the scientific objectives that drove activities and changes, and some of the key events and individuals involved.
\end{abstract}

\section{Introduction: what is cryospheric science?}

The term "cryosphere" traces its origins to the Greek word kryos, meaning frost or icy cold. It collectively describes the components of the Earth's surface that contain ice, including snow, glaciers, ice sheets, ice shelves, icebergs, sea ice, lake ice, river ice, permafrost and seasonally frozen ground. Permafrost, however, can be "dry" and therefore the cryosphere also includes any natural material in frozen form. The origin of the term can be traced to the Polish scientist A. B. Dobrowolski in his 1923 book on The Natural History of Ice (Barry et al., 2011).

The cryosphere is an integral part of the Earth system with important linkages and feedbacks generated through its influence on surface energy and moisture fluxes, clouds, precipitation, hydrology, and atmospheric and oceanic circulation. It plays a significant role in global climate, in climate model response to global change and as an indicator of change in the climate system (e.g. Allison et al., 2001). Within the Global Climate Observing System (GCOS; https://public.wmo.int/ en/programmes/global-climate-observing-system, last access: 12 December 2018), variables from the cryosphere are recognized as essential climate variables (ECVs) that critically contribute to the characterization of Earth's climate (Bojinski et al., 2014).

Cryospheric science is a rapidly expanding and increasingly diverse discipline. There is clear recognition that the cryosphere is a critical part of the total Earth system, particularly for climate and climate change. So cryospheric science must include the interactions with the other Earth "spheres". For example, some of the climate-system models in Phase 6 of the World Climate Research Programme (WCRP) Coupled Model Intercomparison Project (CMIP6) include specific ice sheet models; and an Earth System Model-Snow Model Intercomparison Project (ESM-SnowMIP) is a targeted activity of the WCRP Climate and Cryosphere (CliC) project. But cryospheric science also considers glacier and ice sheet modelling; sea ice dynamics and ocean-iceatmosphere interaction; ice mechanics and rheology; and 


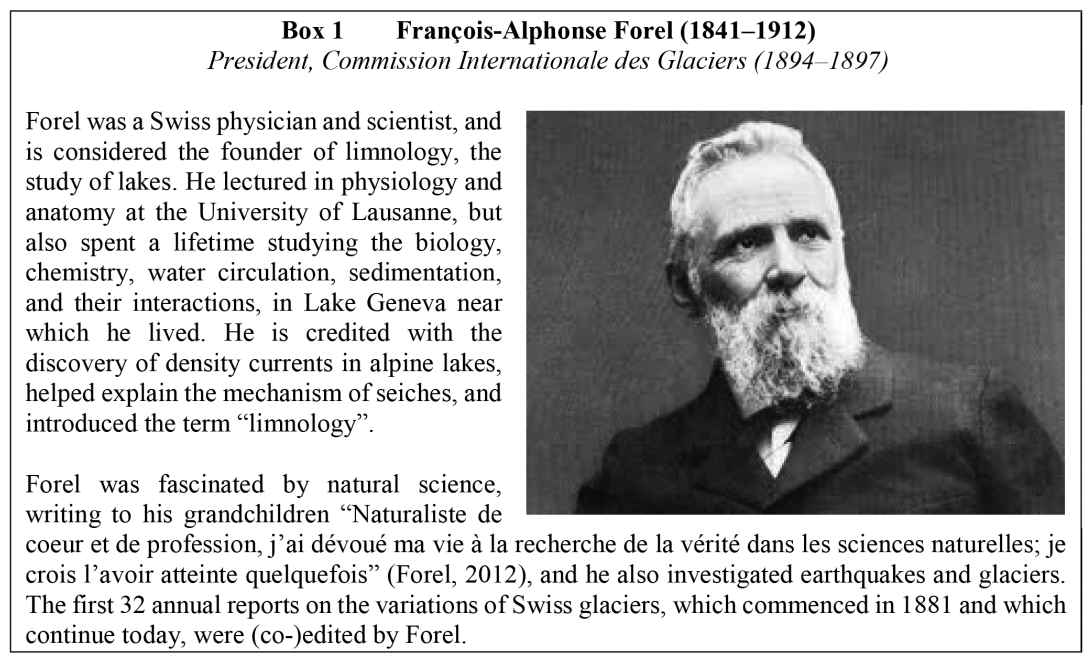

Box 1.

atmosphere-snow interaction, including chemistry, snow redistribution by wind, remote sensing and geophysical methods; and much more.

Cryospheric science also includes the applied science of technical and environmental problems, such as hazards in mountains and glacierized regions, particularly avalanches and glacier lake outburst floods (GLOFs); construction on, and transport over, snow, ice and permafrost surfaces; shipping in ice-covered oceans, lakes and rivers; icing of ships, aircraft and structures; and recreational and tourism activities in snow-covered regions. It also includes studies of the cryosphere elsewhere in the solar system.

In this account of the development of international cryospheric institutions, we draw extensively on prior histories of the Commission Internationale des Glaciers (CIG) and its successor, the International Commission of Ice and Snow (Radok, 1997) and on the transition into the independent association, the International Association of Cryospheric Sciences (IACS; Jones, 2008).

\section{The Commission Internationale des Glaciers (CIG) (1894-1927)}

Systematic collection of information about ongoing glacier changes was initiated on 31 August 1894 when the Council of the sixth International Geological Congress, meeting in Zurich, Switzerland, agreed to create the Commission Internationale des Glaciers.

Earlier, in 1879, François-Alphonse Forel (Box 1) had started annual observations of the variation of glacier fronts in the Swiss canton of Valais. He wished to determine if there was a link between these and changes to the level of Lake Geneva (Lac Léman) and subsequent flooding. Noting that there was no theory to explain glacier variations, he motivated systematic observations in other countries, including
France, where a similar network was established by Prince Roland Bonaparte, who had explored and described glaciers in the French Alps and the Pyrenees in the 1870s and 1880s. But it was Captain Marshall Hall of the Wiltshire Militia, a Fellow of the Geological Society of London and who had worked with Forel in the Swiss Alps in the 1880s who, on behalf of the three, presented the formal proposal for the creation of the CIG to the International Geological Congress Council.

Hall's 1894 letter to the International Geological Congress noted that, by this time, several (mostly European) countries compiled reports on glacier frontal variations, although there was little information on glaciers in other regions such as the Arctic and Antarctic, Scandinavia, Iceland, Greenland, the Himalayas, America, and New Zealand. He suggested that the results obtained in each country would be more useful for investigation of the influence of climate on the variations in the size of glaciers if combined into a single annual report (which could also encompass meteorological data). $\mathrm{He}$ proposed the creation of a commission, composed of one or more members from each country, who would select a national "recorder" to report each year on glacier fluctuations to the president of the commission. The president would assemble these as a combined report in a single language (French). While each country would be independent in the study of its glaciers, the commission would indicate observational guidelines to make the national reports comparable with one another. Forel provided the theoretical and conceptual framework for the commission and became its first president. Prince Bonaparte provided funds for the work of the commission.

A preliminary report by Forel (1895) contained technical concepts and general principles for the CIG. In this he highlighted the importance of glacier observations that would support development of a theory of the relationship between 


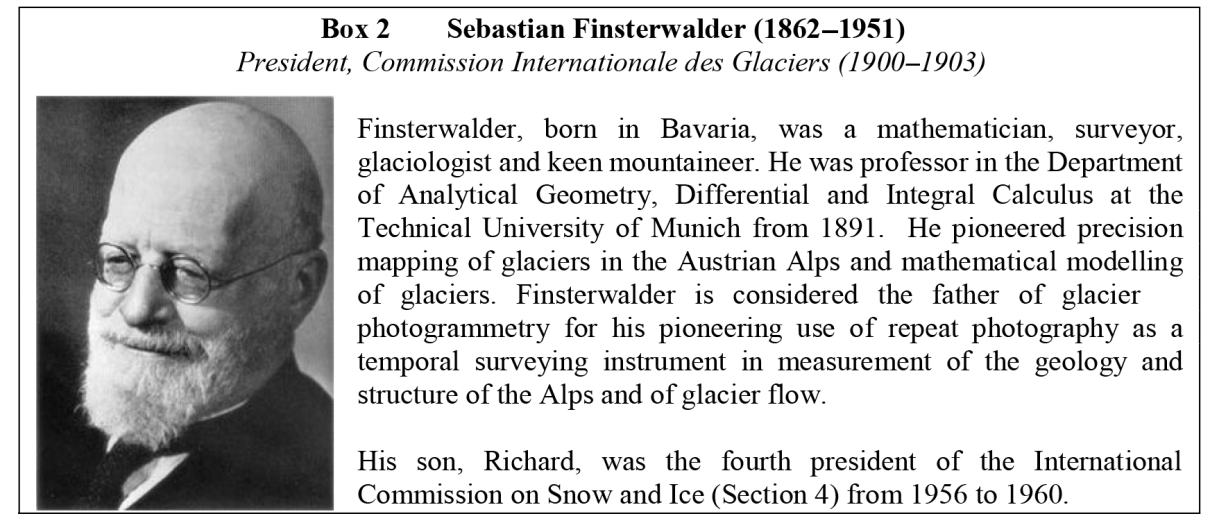

Box 2.

glacier variations and meteorological conditions. But he also recognized that the individuality of different regions required that the collaborators should be free to determine the glacier monitoring tasks needed to address the fundamental scientific interests of the CIG. The first CIG report on observations of glacier variations made in 1895 in various parts of the world was published by Forel and Du Pasquier (1896). President Forel also reported to the next International Geological Congress in St Petersburg in 1897 at the end of his 3 -year term, addressing the basic concepts and methods used in recording glacier variations.

The five CIG presidents that followed Forel reported to successive International Geological Congresses up to 1913, although each outgoing president's report differed widely in content depending on their field of expertise. For example, at the 1903 Vienna Congress the third president, Sebastian Finsterwalder (Box 2), outlined a mathematical formulation for the changes to glacier size and shape in response to changes in snow accumulation and ablation. And at the 1906 Congress in Mexico City the fourth president, Harry Fielding, Professor of Geology at The Johns Hopkins University, Baltimore, reported the first data from Antarctica and compared different national formulations of data for the CIG. Altogether, the preliminary report plus nineteen reports on annual observations were published by successive CIG presidents. The CIG reports on glacier variations ended at the outbreak of the First World War.

The final CIG president, Axel Hamberg, Professor of Geography at Uppsala University, Sweden, was elected by postal vote as only one CIG member was able to travel to the 1913 Toronto Congress. Paul-Louis Mercanton (Switzerland) became secretary of the commission. The activities of the CIG then stalled with the outbreak of the First World War, although Hamberg and Mercanton remained as nominal officers until 1927. A chronology of all seven CIG presidents and the secretaries is available at https://wgms.ch/about_history/ (last access: 12 December 2018).

\section{The International Commission of Ice and Snow (ICSI/IASH): first period (1927-1965)}

On 28 July 1919 in Brussels, nine of the founding national members of the International Research Council (IRC) established the International Union of Geodesy and Geophysics (IUGG) (Union Géodésique et Géophysique Internationale, UGGI). The IRC initially specifically excluded Germany and the other "central powers" of the war from joining it or its various disciplinary unions, and it was not until 1926 that this restriction was revoked. In 1922, in Rome, a Section d'Hydrologie Scientifique (SHS) was launched within IUGG. This was, in 1930, renamed as the International Association of Scientific Hydrology (IASH).

Establishment of a Commission de Glaciologie ${ }^{1}$ as one of four commissions within SHS had been proposed in Rome in 1922. But Hamberg also proposed to seek re-establishment of CIG at the next International Geological Congress. So, in Madrid in 1924, Mercanton persuaded SHS to postpone the decision to establish a Commission de Glaciologie until 1927 to avoid any duplication. Hamberg's 1926 appeal to the International Geological Congress Bureau for reconstitution of the CIG was unsuccessful (Baird, 1958). Reconstituting a glacier group within IUGG became increasingly attractive after the IRC statutes were amended to allow the former "central power" nations to join and also since IUGG could provide some funding to support activities, whereas the International Geological Congress did not. So, at the September 1926 meeting of the SHS Executive Committee (EC) in Geneva, Mercanton proposed to formally disband CIG and replace it with the SHS Commission de Glaciologie. This proposal was agreed to, even before the general assembly. The Commission de Glaciologie was then formally approved at the 1927 Prague IUGG General Assembly, after 16 of 18

\footnotetext{
${ }^{1}$ Commission de Glaciologie, Commission Glaciologique, Commission pour la Glaciologie and Commission des Glaciers were used interchangeably in the SHS and IASH Bulletins Nos. 1 to 20 from 1924 to 1933 .
} 


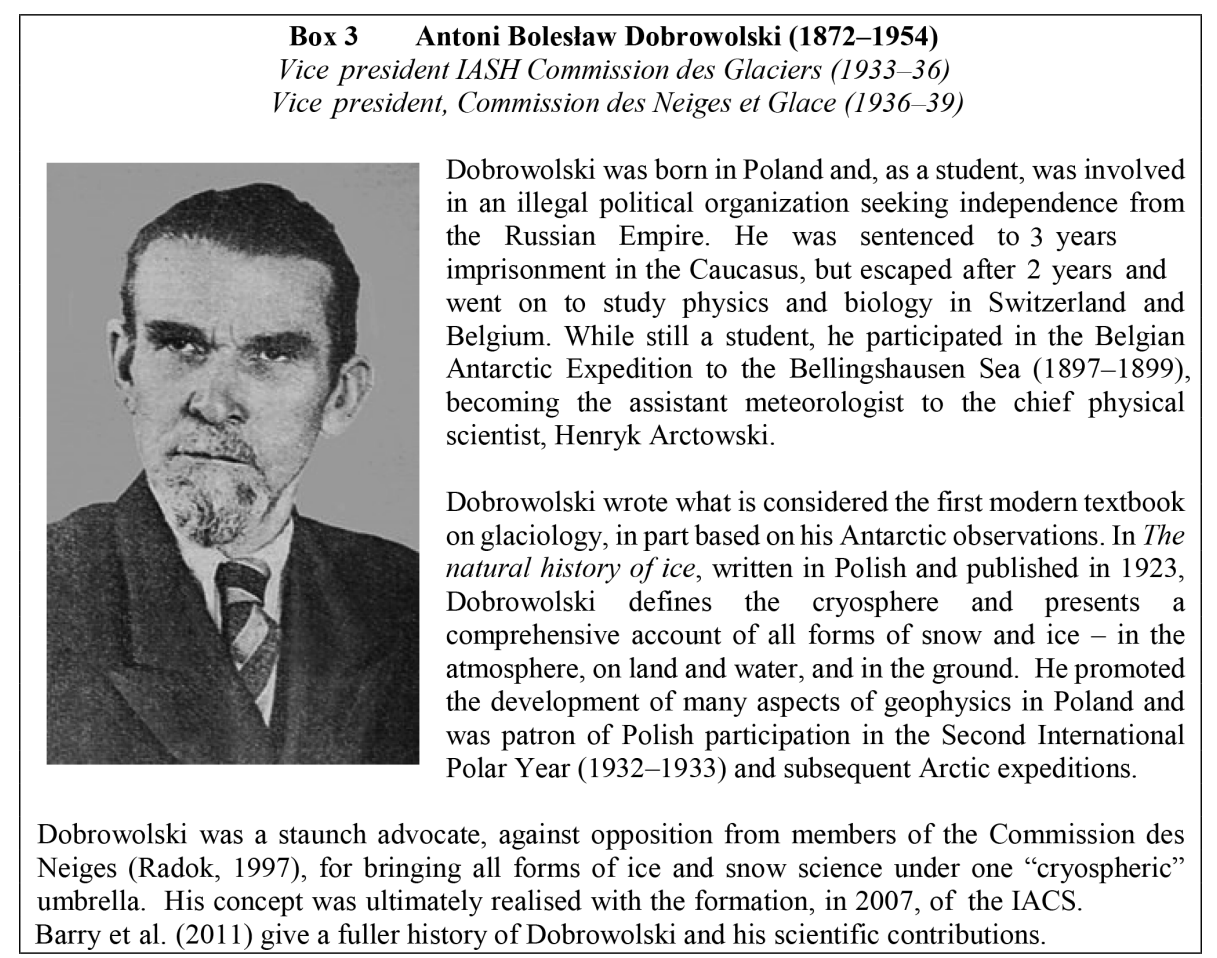

Box 3.

CIG members agreed to dissolve their commission. Although Hamberg had initially wanted to resign, he was persuaded by other members of the CIG to remain as president of the SHS commission. Mercanton became secretary and Charles Rabot (France) was elected vice president. All three had been previously involved in the pre-war CIG, although that had not been active for 13 years.

Hamberg published articles on the "fate" of the CIG and guidelines for the measurement of glacier fluctuations (Hamberg 1930a, b). The new group also published an update of glacier fluctuations spanning the gap since the start of the war (Hamberg et al., 1930). Hamberg then resigned as president at the 1930 general assembly of IUGG.

A decision to establish a Commission des Neiges was made at the 1933 general assembly. The first president, J. E. Church (USA), had previously established a similar snow commission within the American Geophysical Union, which was then the American National Committee of IUGG. Although Mercanton had initially wanted to limit the scope of the Commission des Neiges to snow hydrology, by 1936 it was considering all fields of glaciology not covered by its sister commission. The next assembly (Edinburgh, 1936) included a joint symposium of the two commissions. This was strongly supported, with 80 papers contributed to a very large volume of the Red Book series (No. 23, with a high publication cost for IASH). It included a paper by A. B. Dobrowolski (Box 3) proposing creation of a single "Association of Cryology" within IUGG. Although this was rejected in 1939
(Washington), and not fully accepted for more than another 70 years, the 1939 general assembly did agree to merge the two committees into a single Commission des Neiges et des Glaciers, with J. E. Church as president. Church noted that the original CIG purpose had broadened to encompass all aspects of the modern science of snow and ice "with its multiple relationships and human services".

Activities then paused until the first post-WWII general assembly in Oslo in 1948. Here the Commission des Neiges et des Glaciers was renamed as the International Commission on Snow and Ice (ICSI), a name and general function it was to retain for more than 50 years. The first ICSI president was Hans W. Ahlmann (1948-1951; Sweden). He had extensively investigated the glaciers surrounding the North Atlantic (including Norway, Sweden, Iceland, Greenland and Svalbard) and later became Sweden's ambassador to Norway (19501956) and president of the International Geographical Union (1956-1960).

By this time, the ICSI was forging a network of glaciologists worldwide. For example, the second president, Gerald Seligman (Box 4), was also the founder of the International Glaciological Society (IGS) and the Journal of Glaciology. Many in this network became leading figures in the then incipient international polar expeditions. The foundation ICSI president, Ahlmann, was one of the initiators of the first of these, the Maudheim expedition to Antarctica (1949-1952), which became a prelude to the International Geophysical Year (IGY; 1957/1958). And the third ICSI president, Robert 


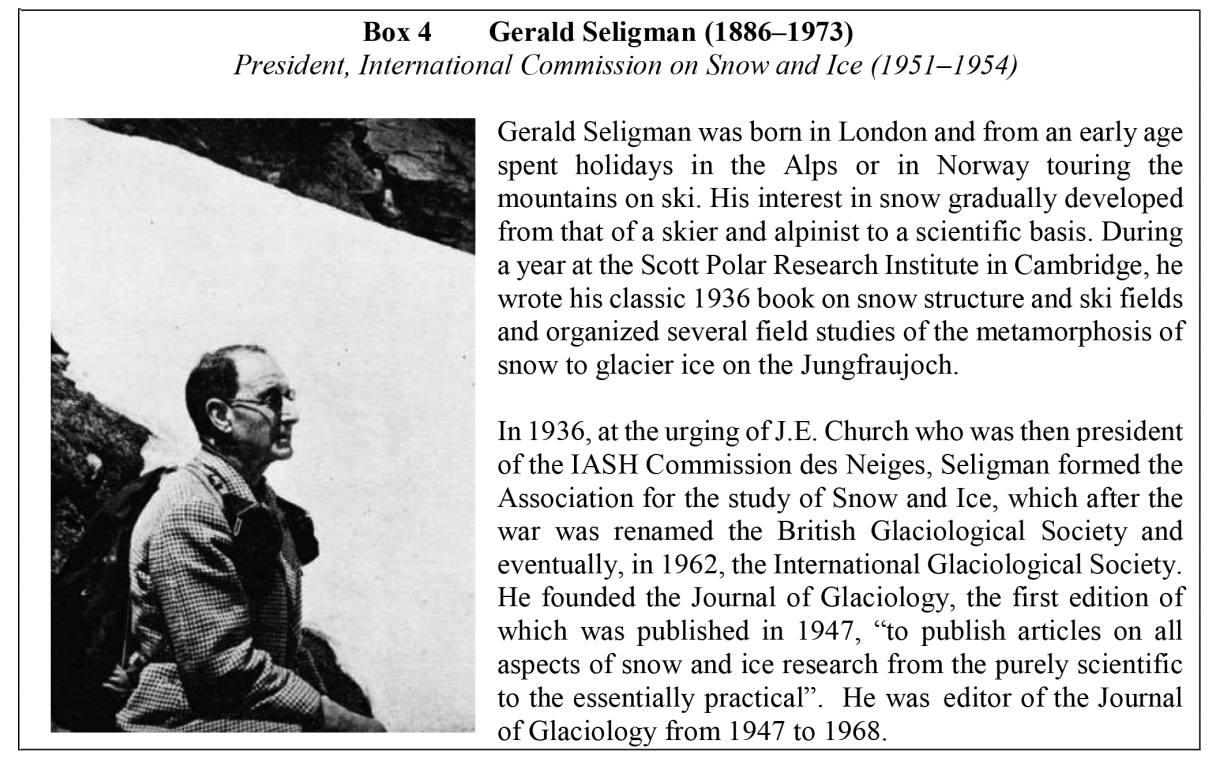

Box 4.

Haefeli (1954-1957; Switzerland), was also the first president of the committee directing the Expédition Glaciologique Internationale au Groenland (EGIG; 1957-1960).

A major function of ICSI throughout this period was organization of snow- and ice-related symposia within the 4yearly IUGG general assemblies, and to publish the proceedings of those in the IASH Red Book series, commencing with the 1936 Edinburgh joint Snow and Ice Symposium (No. 23, 1939) (http://www.cryosphericsciences.org/ publications.html, last access: 12 December 2018). From 1958 this included specialized snow and ice symposia held between the IUGG assemblies, commencing with a symposium in Chamonix on Dynamics of Glacier Movement. Planning for, and results from, the IGY dominated much of the discussions of ICSI at its Rome (1954), Toronto (1957), and especially Helsinki (1960) assemblies. In 1958, the USSR National Committee for IUGG proposed the formation of a separate snow and ice association, noting especially the contributions and advances made during IGY and the climate links of snow and ice. This proposal was not, however, accepted.

\section{The International Commission of Ice and Snow (ICSI/IAHS): second period (1965-2004)}

By the mid-1960s, ICSI/IAHS ${ }^{2}$ had become organized into four divisions dealing with glaciers and ice sheets; seasonal snow cover and avalanches; sea, lake and river ice; and ground ice.

\footnotetext{
${ }^{2}$ In 1971, the International Association of Scientific Hydrology was renamed the International Association of Hydrological Sciences (IAHS).
}

The UNESCO-sponsored International Hydrological Decade (IHD; 1965-1974) provided a major incentive for world-wide hydrological process-oriented investigations and mapping of the water reserves in glaciers and permanent snow fields (Hoinkes, 1968). ICSI established close links with UNESCO and took a lead role in IHD. ICSI presidents Herfried Hoinkes (1963-1967; Austria) and Mark Meier (1967-1971; USA; Box 5) designed and encouraged the snow and ice programs of IHD/IHP, which were then implemented on a national basis. Of particular significance was the program of "Combined Heat, Ice and Water Balances at Selected Glacier Basins". A number of glaciers were selected to represent all major climatic conditions, and standard measurements which could be compared with one another were undertaken for the duration of IHD. The IHD mass balance glossary (ICSI, 1969) and measurement guidelines (UNESCO/IASH 1970, 1973) established standards for harmonizing the monitoring and provided guidelines to create glacier inventories, establishing a glacier coding that is related to hydrologic watersheds. Also, building on the snow expertise of ICSI, a guide for measurement, compilation and assemblage of data for the seasonal snow cover was issued (UNESCO/IASH/WMO, 1970). The International Hydrological Program (IHP) was established as a successor to IHD and is still an active UNESCO program.

As president from 1975 to 1979, Uwe Radok (Australia; Box 6), focused ICSI priority on the role of ice and snow in the climate system, with this leading to the ICSI-sponsored Symposium on Sea Level, Ice and Climate Change at the 1979 general assembly of the IUGG in Canberra. Other symposia on snow and ice science, both as part of IUGG assemblies and during intervening years, continued to be organized by ICSI with proceedings published in the IAHS Red 


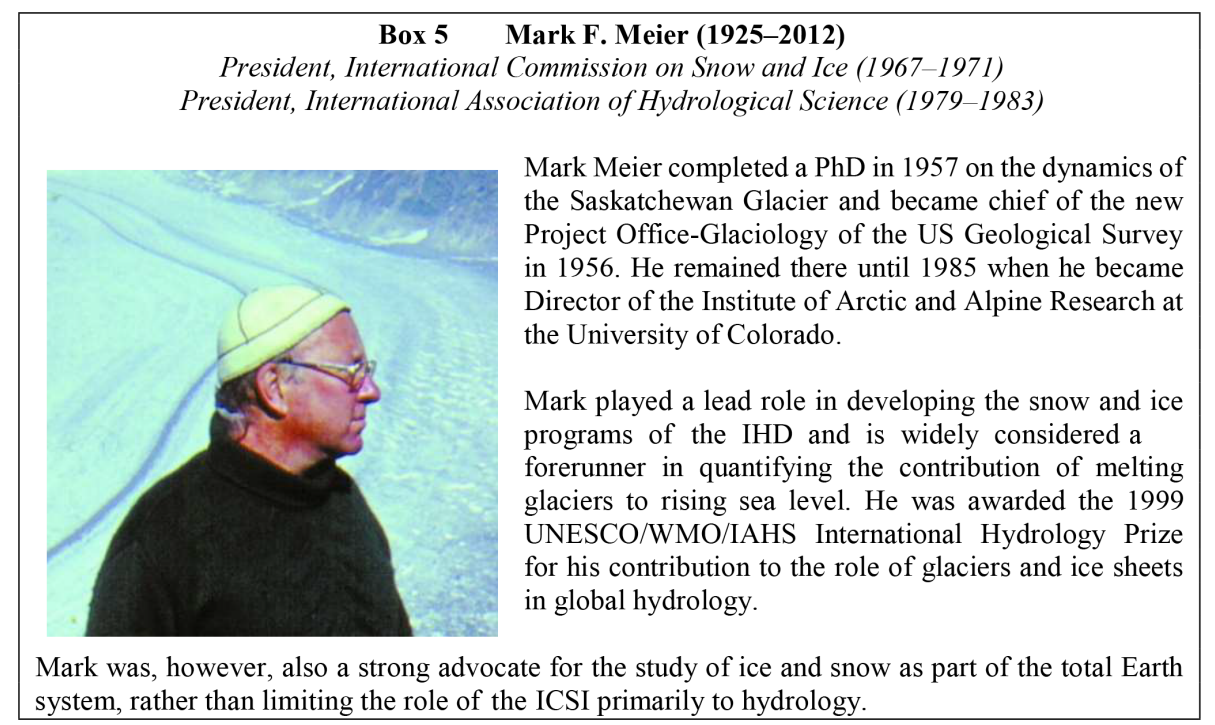

Box 5.

Book series. These included a broad range of cryospheric topics such as glacier fluctuation, snow physics and chemistry, avalanches, Antarctic glaciology, glacier hydrology, and snow processes.

The concept of a separate association for cryology, first proposed by Dobrowolski in 1936 and with a widened range of scientific interest beyond the hydrological focus of IAHS, resurfaced throughout this period. For example, President Louis Lliboutry (1983-1987; France) was concerned that many glaciologists were not attracted to ICSI sessions, which were part of IAHS assemblies. And Mark Meier, during a 1994 keynote speech on the centenary of the formation of CIG, emphasized that a primary focus on hydrology was contrary to the role that snow and ice play in the dynamics of the atmosphere, the surface of the land, the oceans, the solid Earth itself and the biosphere (Jones, 2008).

Throughout this period, key advances were also made in small Working Groups (WGs) that were commissioned and supported by ICSI. These included WGs on large-scale effects of seasonal snow cover, problems of snow and ice hydrology in glacierized regions, and remote sensing of ice and snow. Two innovative WGs, SnowMIP1 and SnowMIP2, comprehensively undertook, for the first time, snow model intercomparison projects. SnowMIP1 compared 23 models using observed meteorological parameters from two alpine sites and focused on the validation of snow energy-budget simulations (Etchevers et al., 2004). SnowMIP2 continued the studies and was also adopted as an activity of the WCRP Global Energy and Water Exchanges (GEWEX) Land Atmosphere System Study (GLASS) and the WCRP CliC project (Essery et al., 2009). Also important were training programmes and technology transfer to less-developed countries, such as the ICSI/UNESCO snow and avalanche pro- grammes in 1981 (Islamabad, Pakistan), 1983 (Kathmandu, Nepal) and 1987 (Manali, India).

In 1995, Liz Morris (Box 7), became the first woman president of ICSI, and the first person to serve two terms in this position (1995-2001).

\section{From ICSI via UCCS to IACS}

It was Liz Morris who initiated and H. Gerald (Gerry) Jones (president-elect, 1999-2001, Box 8) who coordinated the first steps in the successful transformation of the ICSI into the IUGG Association of Cryospheric Sciences (IACS). A discussion paper, concluding that the best option for representing all cryospheric fields would be an independent association within IUGG, was presented to, and accepted by, the ICSI Bureau at the Sixth Scientific Assembly of IAHS at Maastricht in 2001. This was also presented for consideration to the ICSI plenary and to the president of the IAHS.

Liz Morris, Gerry Jones and Georg Kaser (1999-2003 secretary of ICSI) then drafted a position paper for submission at the 2003 Sapporo general assembly, proposing that the IUGG approve and implement a new International Association for Cryospheric Sciences (IACS) and recommending the necessary steps for this. The position paper was developed in consultation with other snow and ice scientific bodies and with assistance from other ICSI officers. In February 2003 it received, through the office of the secretary general Pierre Hubert, support from IAHS. The proposal was formally submitted to IAHS and the IUGG Executive Committee (EC) at Sapporo in March 2003. President Gerry Jones, supported by the new president-elect Georg Kaser, made a strong case for IACS. The IUGG EC responded positively, although it requested that more details on the proposal should be submitted to its next meeting and recommended that an interim inter- 


\title{
Box 6 Uwe Radok (1916-2009)
}

President, International Commission on Snow and Ice (1975-1979)

Radok was born in Königsberg, East Prussia. As a young university student, he fled Germany for England with his two brothers as Nazism gripped Germany. In 1940 , with the outbreak of war, he was interned in England and eventually (after surviving a vessel torpedoed en route to Canada) shipped to internment in Australia. After the war he completed a $\mathrm{PhD}$ under the noted meteorologist and polar explorer Fritz Loewe who, in Melbourne in 1937, had established the first Australian university meteorology department. He became Loewe's assistant after completion of his $\mathrm{PhD}$ and head of the department on Loewe's retirement.

His research interests covered a wide range of experimental and theoretical studies including atmospheric dynamics, numerical weather prediction, polar glaciology and climate science. In the early 1970s, he was a lead proponent of the International Antarctic Glaciology Project (IAGP), serving for many years as its executive secretary. He left Australia in 1977 for 2

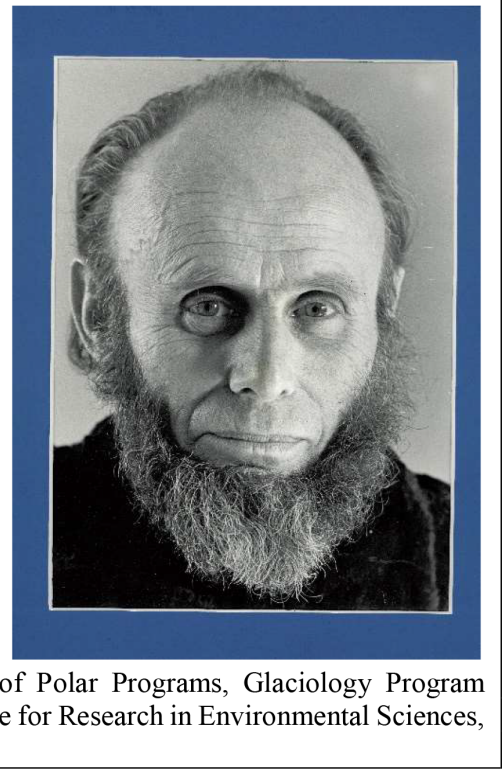

years as the US National Science Foundation Office of Polar Programs, Glaciology Program Manager, and then for a decade at the Cooperative Institute for Research in Environmental Sciences, University of Colorado.

Box 6.

\author{
Box 7 Elizabeth (Liz) Morris (1946- ) \\ President, International Commission on Snow and Ice (1995-2001)
}

Liz Morris grew up in London and studied physics at Bristol. Following her $\mathrm{PhD}$ (1972) she worked first on snow modelling and then on the mass balance and dynamics of polar ice sheets at the British Antarctic Survey (BAS), where she was Head of the Ice and Climate Division (1986-1999). Liz was the first woman to be a division head at BAS, the president of the ICSI and the president of the International Glaciological Society (IGS) (2002-2005). She was one of those who helped initiate changes within BAS which enabled female scientists to over-winter at Antarctic stations.

Liz served ICSI for 20 years in a number of roles, including two terms as president. She led the preparatory process that ultimately transformed the ICSI into the International Association of Cryospheric Sciences. During this she strongly advocated that an IUGG Association of Cryospheric Sciences and IGS, an independent scientific society, would play complementary roles in the science of snow and ice. In $2015 \mathrm{Liz}$ was appointed an Honorary Member of IACS (see photograph in Box $8)$.

Box 7.

association commission be established before a new fully independent association.

Additional information, prepared by a Task Group of Gerry Jones, Georg Kaser and Roger Barry, was presented to the IUGG EC in Boulder in September 2004. The EC unanimously accepted that the ICSI become the Union Commission for the Cryospheric Sciences (UCCS) until ratification of a full new association by the IUGG Council at the next general assembly in 2007. The union commission was created to "prototype" IACS by creating a body separate from the IAHS that could demonstrate to the 2007 council that it had a constituency. It was a deliberate gestation period, and smoothed the way for a positive vote of the EC and the IUGG Council.
In 2005, Georg Kaser (Box 9) became president of the interim UCCS, charged with implementing the transition process and gaining its acceptance within the glaciological community. JoAnn Joselyn (secretary general of the IUGG) and Pierre Hubert (secretary general of the IAHS) were strong and crucial supporters within IUGG. During that time, UCCS officers recruited national committee members, drafted their statutes and by-laws, and all of the other associations (and especially IAHS) had time to adjust to the rather unsettling fact that they were going to have to share IUGG resources with another association.

On 4 July 2007, at the IUGG General Assembly in Perugia, the IUGG Council voted to establish an eighth association, the IACS. This was the first new IUGG associa- 


\section{Box 8 H. Gerald (Gerry) Jones (1936- ) \\ President, International Commission on Snow and Ice (2001-2005)}

Born in Wales, Gerry Jones emigrated to Canada in 1958 for post-graduate study. His research involves holistic studies of cryospheric ecosystems at different scales, with a particular focus on the relationships between the physical dynamics of snow and ice and nutrient pathways and associated metabolic processes in northern and sub-arctic Canadian forest and lake systems.

As the last ICSI president, Gerry worked tirelessly towards the establishment of an IUGG Cryospheric Association. With Georg Kaser and Roger Barry, he submitted the proposal that led to the formation of the UCCS to the IUGG Council at the 2003 General Assembly. He also drafted the statutes and by-laws for the new association, which IUGG later used as a basis for revision of its own statutes. In 2011 he was appointed as the first Honorary Member of IACS.

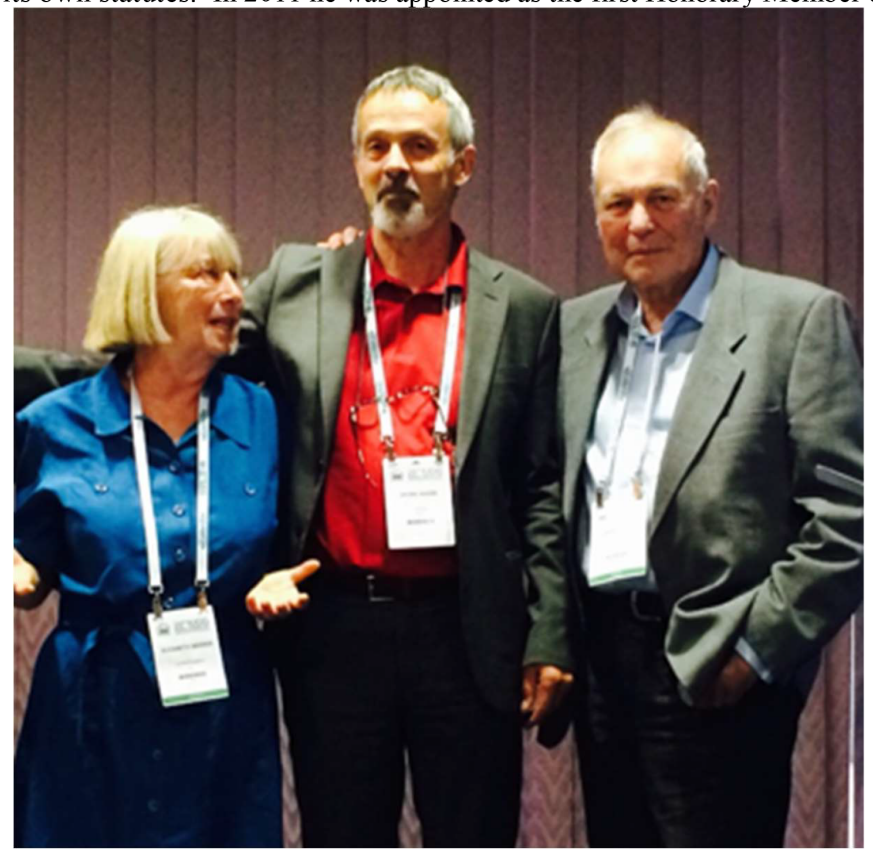

Three presidents during the transition period together at the 2015 IUGG General Assembly (Prague). From left to right: Liz Morris (Box 7), Georg Kaser (Box 9) and Gerry Jones (this Box).

Box 8.

tion in over 80 years. A new IAHS commission, the International Commission for Snow and Ice Hydrology (ICSIH), was also formed in 2007 to encourage research at the interface between cryospheric and hydrological sciences and to foster a fruitful connection with the IACS. Subsequently in July 2008, a Memorandum of Understanding was forged between IACS, the Scientific Committee on Antarctic Research (SCAR) and the International Arctic Science Committee (IASC) to recognize their common interest in ice and snow on Earth and to co-ordinate activities so as to avoid duplication and overlap.

\section{The World Glacier Monitoring Service (WGMS)}

This paper has recorded the transition from monitoring glacier variability in different parts of the world in response to climate fluctuations (the focus of CIG) to a broader consideration of the role of ice and snow in the total Earth sys- tem (IACS). But there is also an important and more direct legacy of the CIG coordination of international glacier monitoring. Although CIG activities were discontinued at the outbreak of war in 1914, glacier observations continued in different countries and the reporting was renewed with the formation of the IASH Commission des Glaciers in 1927 (Hamberg et al., 1930). They continued until 1959, throughout the difficult periods of the Great Depression and the Second World War, largely due to the efforts of Paul-Louis Mercanton (Switzerland). Mercanton led the compilation and publication of IASH reports on glacier length changes for 19131947 (Nos. 14, 20, 22, 30; for the Alps and Scandinavia, and later including Iceland) and for 1947-1959 (Nos. 32, 39, 46, 54; for Europe). In addition, IASH reports Nos. 20, 30, 32 and 39 contain glacier observations compiled for North America, one addendum for Sweden and two reports for Columbia and Peru respectively. 


Box 9 Georg Kaser (1953- )
President, Union Commission for the Cryospheric Sciences (2005-2007)
President, International Association of Cryospheric Sciences (2007-2009)

Box 9.

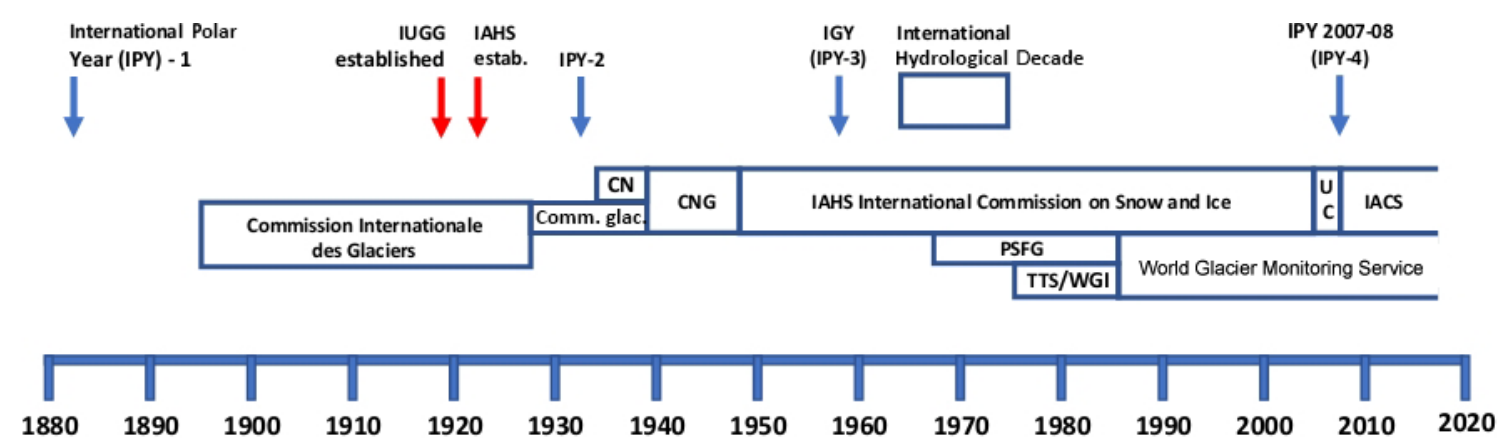

Figure 1. Schematic timeline showing the progression from the Commission Internationale des Glaciers (CIG) to the IUGG International Association of Cryospheric Sciences (IACS). This distinguishes two equally important heritage lines: monitoring glacier fluctuations and their link to climate (bottom) and cryospheric science more broadly (top). It also shows other major scientific programs and events relevant to the progression. ( $\mathrm{CN}=$ IASH Commission des Neiges; Comm. Glac. = IASH Commission des Glaciers; $\mathrm{CNG}=\mathrm{IASH}$ Commission des Neiges et des Glaciers; UC = IUGG Union Commission for the Cryospheric Sciences; PSFG= Permanent Service on the Fluctuations of Glaciers; TTS/WGI = Temporary Technical Secretariat for the World Glacier Inventory.)

On the initiative of Herfried Hoinkes, then president of the ICSI, a pilot study led by Peter Kasser was undertaken to set glacier variation surveys on a new and broader footing. This resulted in the 1967 formation of the Permanent Service on the Fluctuations of Glaciers (PSFG). In 1976, the Temporary Technical Secretariat for the World Glacier Inventory (TTS/WGI) was formed, and in 1986, on the initiative of Wilfried Haeberli, these two ICSI services combined to become the World Glacier Monitoring Service (WGMS).

Today the WGMS continues the collection and publication of standardized information on distribution and ongoing changes in glaciers that were commenced in 1894 (WGMS, 2017). It maintains a network of local investigators and national correspondents in all the countries involved in glacier monitoring. WGMS is co-responsible for the Global Terrestrial Network for Glaciers (GTN-G) within the Global Climate Observing System (GCOS) where it cooperates with the US National Snow and Ice Data Center (NSIDC) in Boulder and the Global Land Ice Measurements from Space (GLIMS) initiative. GTN-G aims to combine field observations with remotely sensed data, process understanding with global coverage, and traditional measurements with new technologies.
The WGMS is a service of IACS within the World Data System (WDS) of the International Science Council. WGMS provides a specific and expert technical function (compilation of standardized data on glacier changes in length, area, volume, and mass) whereas IACS covers a much broader perspective of cryospheric science, although the organizations work closely together. The two complementary streams of development from CIG in 1894 are shown in Fig. 1.

\section{The International Association of Cryospheric Sciences (IACS)}

Since it was formed in 2007, IACS has established itself as an active professional organization within the cryospheric sciences. Its primary objectives are to promote the advancement of cryospheric sciences of the Earth and the solar system; to encourage research in the cryospheric community through collaboration and international co-ordination; to promote education and public awareness on the cryosphere; and to facilitate the standardization of measurement or collection of cryospheric data and of their analysis, archiving and publication. 
IACS is managed by an 11-member elected bureau comprised of the president, the president-elect or immediate past president, three vice presidents and the heads of five divisions covering different aspects of cryospheric science. The divisions are snow and avalanches; glaciers and ice sheets; sea ice, lake and river ice; cryosphere, atmosphere and climate; and planetary and other ices of the solar system. Bureau members are elected for a 4-year term and the Bureau meets at least once per year, although today often by teleconference.

IACS supports standing groups which address scientific problems of the cryosphere that require medium- to longterm reflection. Currently there are three standing groups: "Glacier and Permafrost Hazards in Mountains" (GAPHAZ; jointly with the International Permafrost Association, IPA), "IAVCEI/IACS joint commission on Volcano-Ice Interactions", and the "Global Terrestrial Network for Glaciers GTN-G Steering Committee". It also supports working groups which target timely and well-constrained scientific problems within a limited term (usually 4 years). These are initiated by members of the international scientific community, adopted with majority approval of the bureau, and managed within the most relevant IACS division. Currently, three working groups deal with improving our understanding different aspects of glaciers including the influence of surface debris cover on glacier mass balance, estimating ice thickness from unmeasured glaciers (Farinotti et al., 2017), and completing a standardized global inventory (Arendt et al., 2015). Two previous IACS working groups produced glossaries for glacier mass balance and snow, published by the UNESCO International Hydrological Programme. Both glossaries have become international standards and are highly cited and widely used in the cryospheric community (Fierz et al., 2009; Cogley et al., 2011).

Like all IUGG associations, the IACS organizes and supports major bi-annual scientific meetings. At the quadrennial IUGG general assemblies it promotes union symposia; joint symposia on climate change topics with the IAMAS, IAPSO and IAHS; and other joint symposia with the IAG (on satellite-based systems that are used to observe the cryosphere) and IASPEI (on "cryo-seismology", an exciting new field that provides insight into the structure and dynamics of glaciers and ice sheets, as well as the properties of the Earth's upper crust). At meetings midway between IUGG general assemblies it typically combines with other IUGG associations on an interdisciplinary theme, or with other cryospheric scientific organizations outside IUGG.

\section{Future directions}

The IACS is the youngest association of the IUGG, but at the same time it has a very long history when the precursor organizations discussed above are also included. As a new IUGG association, it is rapidly adopting new ways of work- ing. The IACS actively promotes diversity within its structure. For example, the 11-member bureau for 2015-2019 included more than $50 \%$ female scientists, scientists from 10 different countries and one early-career scientist. IACS also conducts much of its business via electronic communication, including video links and on-line voting on bureau resolutions.

IACS actively supports early-career scientists through provision of travel grants to sponsored scientific meetings and to international training courses, especially supporting student attendance from less-developed countries. It has also established a bi-annual cash prize awarded to two early-career scientists for the best scientific paper on a cryospheric topic.

IACS has offered an individual (free) membership since 2017. In the first 20 months, that grew to nearly 400 individual members.

Cryospheric science is a rapidly growing and evolving field, especially as impacts of climate change, such as glacier contributions to sea-level rise or rapid decline of sea ice, become increasingly evident and recognized. New technologies and remote sensing techniques have, at the same time, revolutionized the discipline. The IACS, particularly with its ability to quickly establish new working groups, is versatile, well-equipped and ready to contribute to meeting scientific challenges and further advancing cryospheric science.

Data availability. The data used for this paper are either available in publications of the CIG and of IAHS (Red Book series) or accessible as downloadable reports and minutes of UCCS and IACS meetings (http://www.cryosphericsciences.org/ documents.html, last access: 21 December 2018).

Competing interests. The authors declare that they have no conflict of interest.

Special issue statement. This article is part of the special issue "The International Union of Geodesy and Geophysics: from different spheres to a common globe" (https://www.hist-geo-space-sci. net/special_issue996.html). It is not associated with a conference.

Acknowledgements. We acknowledge the very helpful support from Christophe Cudennec and Claire Lupton at the IAHS Secretariat. We are also grateful for JoAnn Joselyn's constructive assessment of an early version.

Edited by: Alik Ismail-Zadeh

Reviewed by: Jon Ove Hagen and Pierre Hubert 


\section{References}

Allison, I., Barry, R. G., and Goodison, B. E. (Eds.): Climate and Cryosphere (CliC) Project: Science and Coordination Plan, Version 1. World Climate Research Programme, WCRP-114 (WMO/TD-No.1053), [iii + 75 pp. + 10 pp.], 2001.

Arendt, A., Bliss, A., Bolch, T., Cogley, J. G., Gardner, A. S., Hagen, J. O., Hock, R., Huss, M., Kaser, G., Kienholz, C., and Pfeffer, W. T.: Randolph Glacier Inventory - A dataset of global glacier outlines: Version 5.0. GLIMS Technical Report, 63 pp., 2015.

Baird, P. D.: A Note on the Commission on Snow and Ice of the International Association of Scientific Hydrology, J. Glaciol., 3, 253-256, https://doi.org/10.3189/S0022143000023881, 1958.

Barry, R. G., Jania, J., and Birkenmajer, K.: Review article "A. B. Dobrowolski - the first cryospheric scientist - and the subsequent development of cryospheric science", Hist. Geo Space Sci., 2, 75-79, https://doi.org/10.5194/hgss-2-75-2011, 2011.

Bojinski, S., Verstraete, M., Peterson, T. C., Richter, C., Simmons, A., and Zemp, M.: The concept of Essential Climate Variables in support of climate research, applications, and policy, B. Am. Meteorol. Soc., 95, 1431-1443, 2014.

Cogley, J. G., Hock, R., Rasmussen, L. A., Arendt, A. A., Bauder, A., Braithwaite, R. J., Jansson, P., Kaser, G., Möller, M., Nicholson, L., and Zemp, M.: Glossary of Glacier Mass Balance and Related Terms, IHP-VII Technical Documents in Hydrology No. 86, IACS Contribution No. 2, UNESCO-IHP, Paris, 2011.

Essery, R., Rutter, N., Pomeroy, J., Baxter, R., Stähli, M., Gustafsson, D., Barr, A., Bartlett, P., and Elder, K.: SNOWMIP2: An Evaluation of Forest Snow Process Simulations, B. Am. Meteorol. Soc., 90, 1120-1135, https://doi.org/10.1175/2009BAMS2629.1, 2009.

Etchevers, P., Martin, E., Brown, R., Fierz, C., Lejeune, Y., Bazile, E., Boone, A., Dai, Y. J., Essery, R., Fernandez, A., and Gusev, Y.: Validation of the energy budget of an alpine snowpack simulated by several snow models (Snow MIP project), Ann. Glaciol., 38, 150-158, 2004.

Farinotti, D., Brinkerhoff, D. J., Clarke, G. K. C., Fürst, J. J., Frey, H., Gantayat, P., Gillet-Chaulet, F., Girard, C., Huss, M., Leclercq, P. W., Linsbauer, A., Machguth, H., Martin, C., Maussion, F., Morlighem, M., Mosbeux, C., Pandit, A., Portmann, A., Rabatel, A., Ramsankaran, R., Reerink, T. J., Sanchez, O., Stentoft, P. A., Singh Kumari, S., van Pelt, W. J. J., Anderson, B., Benham, T., Binder, D., Dowdeswell, J. A., Fischer, A., Helfricht, K., Kutuzov, S., Lavrentiev, I., McNabb, R., Gudmundsson, G. H., Li, H., and Andreassen, L. M.: How accurate are estimates of glacier ice thickness? Results from ITMIX, the Ice Thickness Models Intercomparison eXperiment, The Cryosphere, 11, 949-970, https://doi.org/10.5194/tc11-949-2017, 2017.
Fierz, C., Armstrong, R. L., Durand, Y., Etchevers, P., Greene, E., McClung, D. M., Nishimura, K., Satyawali, P. K., and Sokratov, S. A.: The International Classification for Seasonal Snow on the Ground. IHP-VII Technical Documents in Hydrology No. 83, IACS Contribution No. 1, UNESCO-IHP, Paris, 2009.

Forel, F. A.: Les variations périodiques des glaciers. Discours préliminaire. Extrait des Archives des Sciences physiques et naturelles XXXIV, 209-229, 1895.

Forel, F. A.: Forel et le Léman. Aux sources de la limnologie. Presses polytechniques et universitaires romandes, Lausanne, 317 pp., 2012.

Forel, F. A. and Du Pasquier, L.: Les variations périodiques des glaciers. 1er Rapport, 1895, Extrait des Archives des Sciences physiques et naturelles, 101/4, 129-147, 1896.

Hamberg, A.: Das Schicksal der internationalen Gletscherkommission, Geogr. Ann., 12, 112-124, 1930a.

Hamberg, A.: Anleitung zur Messung der periodischen Grössenveränderungen der Gletscher, Geogr. Ann., 12, 125-129, $1930 \mathrm{~b}$.

Hamberg, A., Rabot, C., and Mercanton, P.-L.: Commission des Glaciers: Rapport sur les variations de longueur des glaciers de 1913 à 1928 (Chaîne des Alpes; Scandinavie), IASH Publication No. $14,1930$.

Hoinkes, H.: Glaciology in the International Hydrological Decade, in: General Assembly of Bern, IASH Publication No. 79, 7-16, 1968.

ICSI: Mass-balance terms, J. Glaciol., 8, 3-7, 1969.

Jones, H. G.: From Commission to Association: the transition of the International Commission on Snow and Ice (ICSI) to the International Association of Cryospheric Sciences (IACS), Ann. Glaciol., 48, 1-5, 2008.

Radok, U.: The International Commission on Snow and Ice (ICSI) and its precursors, 1894-1994, Hydrol. Sci. J., 42, 131-140, 1997.

UNESCO/IASH: Combined Heat, Ice and Water Balances at Selected Glacier Basins: A Guide for Compilation and Assemblage of Data for Glacier Mass Balance Measurements, Technical Papers in Hydrology, 5 ["Part 1"]. UNESCO/IASH, Paris, 20 pp., 1970.

UNESCO/IASH: Combined Heat, Ice and Water Balances at Selected Glacier Basins. Part II: Specifications, Standards and Data Exchange, Technical Papers in Hydrology, 5, UNESCO/IASH, Paris, 32 pp., 1973.

UNESCO/IASH/WMO: Seasonal snow cover. A guide for measurement, compilation and assemblage of data, Technical Papers in Hydrology, 2, UNESCO/IASH/WMO, Paris, 38 pp., 1970.

WGMS: Global Glacier Change Bulletin No. 2 (2014-2015), edited by: Zemp, M., Nussbaumer, S. U., Gärtner-Roer, I., Huber, J., Machguth, H., Paul, F., and Hoelzle, M., ICSU(WDS)/IUGG(IACS)/UNEP/UNESCO/WMO, World Glacier Monitoring Service, Zürich, 244 pp., 2017. 